\title{
Abstract
}

There is increasing evidence that NGOs and Government agencies are turning to sport events as a tool for reconciliation and inter-community peace projects (Burnett, 2006; Gasser \& Levinsen, 2004; Stidder \& Haasner, 2007; Sugden, 2006), yet the different roles and responsibilities of the organising 'change agent' within development projects has not received much empirical investigation. To address this gap, this paper analyses the different roles and responsibilities of an international sport event change agent in the ethnically divided Sri Lanka. Following an interpretivist mode of inquiry, findings of this research are derived from the analysis of two focus groups and 35 in-depth interviews with Sinhalese, Tamil, Muslim and international event stakeholders.

The findings suggest that the change agent holds nine key roles and responsibilities in the inter-community development process. These are being an agent for community participation; a trust builder; a networker; a leader; a socially responsible advocate; a resource developer; a proactive innovator; a financial supporter; and a strategic planner for the long-term sustainability of projects. This research suggests that it is important to fulfil these roles to secure active community participation, to achieve positive socio-cultural event impacts and outcomes, and to provide a strategic framework for sustainable inter-community

21 development.

Keywords: Strategic Sport Management; Change Agent Roles; Community Development; 


\section{THE ROLES AND RESPONSIBILITIES OF A CHANGE AGENT IN SPORT EVENT DEVELOPMENT PROJECTS}

\section{Introduction}

According to Arai and Pedlar (2003), three interrelated crises are apparent at the commencement of the twenty-first century: a political crisis, a social crisis, and an identity crisis. On the political level - particularly in multicultural societies - governments have to deal with demands and requirements from different groups representing specific cultures, values and ideas. On a social level - particularly within divided countries - communities struggle to live in peace and harmony with their neighbours, which may result in intergroup conflicts and in extreme cases, civil war. On the identity level, people are having difficulties in connecting emotionally with others, their communities, ethnic groups or homeland. In dealing with these crises, Non Governmental Organisations (NGOs) have been promoting community participation ideals, programs and projects to engage people, to give them a voice, and connect them with others in a meaningful way. International voluntary agencies such as the International Centre for Ethnic Studies, as well as national conflict resolution organisations such as the National Peace Council have been largely enthusiastic about the active involvement of the community into social development programs.

The community participation approach is now seen as an innovative and practicable form of social development, in which particular interest is given to developing countries and the idea of 'guided self help’ (Midgley, 1986; Orjuela, 2003; Uruena, 2004). Many experts believe that communities - particularly those in developing countries - cannot function autonomously without the guidance and help of skilled 'change agents', which support and teach them how to cooperate and use their capacities effectively (Ife, 1995; Lawson, 2005; Uruena, 2004). Adapted from Mitchell's (1990) definition of 'third parties', a change agent is defined as: 
an external party who helps adversaries establish contact, open negotiations and develop projects for cooperation and sustainable development to end a dispute in a mutually satisfactory agreement.

A change agent can be either a well-trained individual employer or a specialised organisation, such as a development agency or an NGO, that supports bottom-up community projects (Burnett, 2006; Hollnsteiner, 1979; Orjuela, 2003; Spergel, 1969; Wilson, 1997). Within a community participation framework, one creative and dynamic way towards interaction and intercultural togetherness is the use of sport events, which provide unique entertainment experiences for community members, and engage them in entertaining social environments. This paper focuses on the different roles and responsibilities of an international event organisation that acts as a change agent in the management of development projects in the ethnically divided Sri Lanka. The paper forms part of a broader study which analyses the role of sport events in contributing to social development between disparate communities.

\section{Literature Review}

The concept of community development through participation has been introduced as a promising strategy towards project initiation, socio-cultural development and overall community empowerment (Gschwend \& Selvaranju, 2007; Henley, 2005; Reid, 2003, 2006). To achieve these aims, aid organisations and NGOs have recently advanced a middle path that emphasises the obligation of the state to ensure the wellbeing of the communities by creating an enabling environment for private initiative, and the right of the people to decision-making power (Burnett, 2006; Reid, 2006). With the help of change agents, who facilitate development projects and foster grass-roots participation, people and communities from different backgrounds are integrated into a social network, in which they 'rub shoulders' in common tasks and seek common goals. The importance of a change agent within this 
strategic and sustainable community development process is highlighted by Kramer and Specht (1975: 14), who explain:

A professional change agent helps a community action system composed of individuals, groups, or organizations to engage in planned collective action in order to deal with social problems within a democratic system of values. It is concerned with programs aimed at social change.

In cooperation with a change agent local communities can work towards beneficial long-term project outcomes, social development and desired change. Within this process, the change agent is expected to mobilise support and inculcate an attitude of confidence and co-operation amongst participating community groups and their respective members (Midgley, 1986). For example, in their sport reconciliation project in Israel's Galilee region, Sugden (2006) and Stidder and Haasner (2007) found that carefully planned sport and education activities between international sport experts and local community leaders can make a valuable contribution to reconciliation and co-existence in deeply divided communities. They can be designed to be tangible and sustainable products that local coaches, teachers and community leaders can continue to promote through the teaching of newly learnt skills, core values and principles. Such activity based education programs include inter alia work shops, collaborative group work such as routine planning, expedition, orienteering, raft building or trust games. External knowledge can be transferred to the local communities, who are encouraged to continue the reconciliation and peace-building work with the newly acquired methods, skills and activities.

When projects are initiated or guided by outsiders there is, however, the danger that they may employ a dominant paternalistic approach to management (Botes \& van Rensburg, 2000; Stiglitz, 2002). The change agent may unconsciously or consciously have the feeling of 'knowing what's best' for communities, which may result in local input being undervalued 
(Midgley, 1986; Willmott, 1988). The misuse of power and the drift from a 'bottom up' towards a 'top-down' approach may prohibit communities to show and experience their own full potential, and might lead to community uncertainty and resistance (Skinner, Zakus, \& Cowell, 2008; Vail, 2007). Initially, Western change agents may not have the skills to ‘culturally work' with a developing country’s socio-cultural context, which means that only a fruitful cooperation between communities and change agents may lead to local empowerment of people and groups (Avery, 2004; Schulenkorf, 2008).

When working on community building projects, several authors highlight the importance of establishing a clear strategy and setting lucid goals to achieve sustainable social development (Lawson, 2005; Naparstek, Dooley, \& Smith, 1997). Within a sport event context, strategic and cooperative ex ante planning is required from all stakeholders to not only generate direct event impacts, but to then leverage these impacts to achieve long-lasting positive outcomes (Chalip, 2004, 2006; Kellett, Hede, \& Chalip, 2008; O'Brien, 2007; Danny O'Brien \& Laurence Chalip, 2007; D. O'Brien \& Laurence Chalip, 2007; Schulenkorf, 2009). From the beginning of the event management process the communities and the change agent should have a clear idea about the desired long-term outcomes of sport events, in order to plan and manage accordingly. This ex ante strategic management process is presented in Figure 1 below. 
Figure 1: Strategic management process for long-term event outcomes

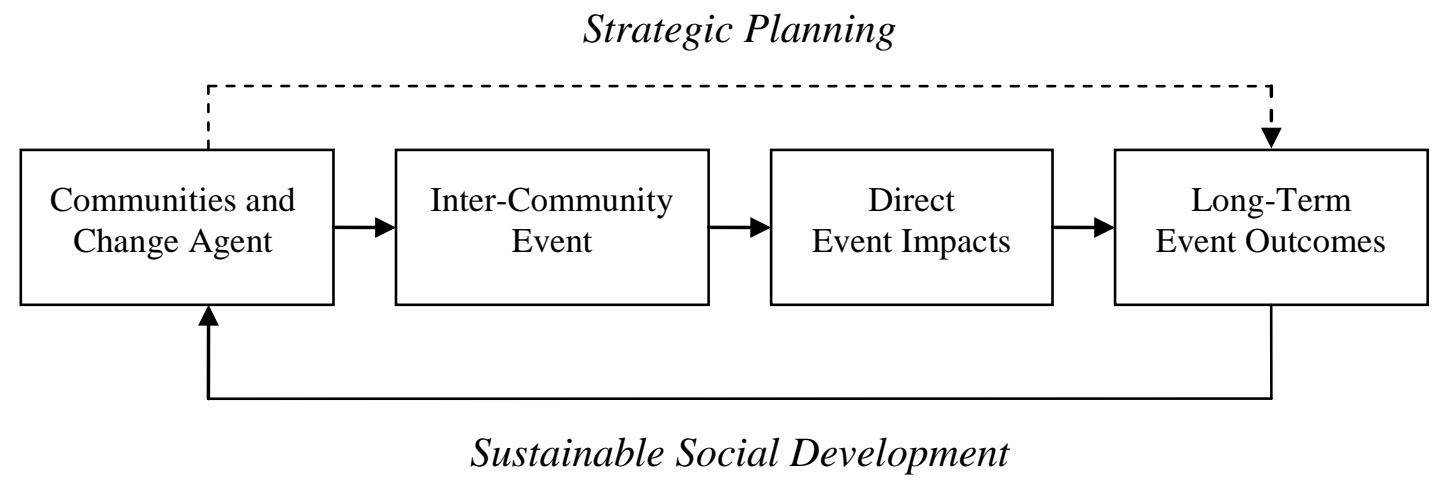

Within this strategic management process, the change agent is serving not as a dictating force but as a supportive facilitator for projects and networks of partnerships between residents, management, and community organisations (Kramer \& Specht, 1975; Sanoff, 2000; Schulenkorf, 2008). Two examples from sport programs in South Africa demonstrate the success of such bottom-up community programs, which are supported by an international NGO as the change agent. The “Australia-South Africa Junior Sport Programme” and the “Active Community Clubs Initiative” were introduced by the South African Government in cooperation with Australian sport and development experts (acting as change agents). Both projects had an ex ante focus on achieving lasting program outcomes and centred on the principle of 'building development around people' (Burnett, 2001, 2006). They provided equitable sports opportunities for the disadvantaged youths in an attempt to develop a broad participation base, which at times even led to elite sport participation.

Burnett (2001; 2006) argues that the leisure context of the South African projects was conductive to community participation and the establishment of a positive intergroup atmosphere. She believes that an even bigger success factor was, however, the inclusion of the external change agents who acted as impartial supporters within both programs. The 
change agents' presence and involvement contributed to an enhancement of community development through establishing reciprocal trust, respect, self-esteem, and overall wellbeing within communities. In an attempt to sustain these positive developments, both of the South African sport development projects implemented cascade structures to 'train the trainers', whereby the change agent trained local coaches to train others as part of a 'training network' (Burnett \& Uys, 2000). This network guaranteed a combination of innovative external and internal experiences, strategies and content to meaningfully address the needs of the local communities. In both projects, a steady increase in participation and the implementation of follow-up community activities indicate positive and sustainable (inter-)community development (Burnett, 2006).

The strategic planning for the maximisation of event benefits is referred to as event leverage (Chalip, 2004, 2006; Kellett et al., 2008; O'Brien, 2007; D. O'Brien \& Laurence Chalip, 2007). While previously event managers and researcher have taken an ex post perspective on evaluating events according to the direct impacts that they generated, the recent trend goes towards an ex ante planning for sustainable event outcomes. In other words, an ex ante strategy presents a focus on growing positive impacts beyond event borders, and 'making things happen', rather than leaving them to chance. Most of the available studies on event leverage refer to opportunities stemming from large-scale or mega events (Chalip, 2004, 2006; Kellett et al., 2008; O'Brien, 2006; O'Brien \& Gardiner, 2006). Furthermore, leveraging for tourism and business opportunities has dominated the research focus (Chalip \& Leyns, 2002; Chalip \& McGuirty, 2004; O'Brien, 2006) and there is little empirical evidence supporting the claim that smaller community events can use and benefit from social event leveraging (for an exception see O'Brien, 2007). Currently there is no empirical research available on leveraging opportunities that facilitate sustainable social development and peaceful togetherness in a developing world context. It still needs to be identified which 
strategies, partnerships and support programs are the most suitable to maximise social benefits for event communities in general, and disparate communities in particular.

Overall, the available analyses of intergroup sport programs and events in a developing world context highlight sport's capacity to contribute to social development (see Burnett, 2006; Gasser \& Levinsen, 2004; Schulenkorf, 2008; Stidder \& Haasner, 2007; Sugden, 2006). However, Hariharan (2006) argues that an understanding of the involvement of external change agents such as NGOs in conflict-resolution and intergroup development is minimal. To fill this gap, this study presents an empirical analysis of the specific roles and responsibilities of change agents within inter-community event management processes, which is needed to find a balance between the wants and needs of the participating communities and the external change agent.

\section{Method}

This research employed a case study approach to examine organisers' and communities' opinions about the different roles of a change agent at inter-community sport events in rural Sri Lanka. Within social science, a case study is not simply a single, coherent form of research - according to Stark and Torrance (2006) it is rather an 'approach' to research which is supported by a theoretical base consisting of social interaction and social construction of meaning. The international event organiser Asian German Sports Exchange Programme (A.G.S.E.P.) was identified as the change agent for this research. Since 1989, A.G.S.E.P. has been engaged in sport exchanges and international events between Asian and European sport teams that provided inter-cultural experiences for more than 5000 participants. For the last ten years A.G.S.E.P. has changed its primary focus towards integrating sportspeople of Sri Lanka's different ethnic groups in inter-community sport camps, events and workshops. 
Under the motto of 'Connecting Sportspeople', special focus is placed on providing social sport and leisure opportunities for rural Sri Lankan communities from all over the island, including the often neglected north eastern parts of the country. In steady co-operation with Sinhalese, Tamil and Muslim community groups and international volunteers, A.G.S.E.P.'s vision is "to contribute to the re-establishment of peace in Sri Lanka", while its overall mission is "to popularise social values such as respect, courage and commitment through sport events” (A.G.S.E.P. Website, 2008).

\section{Setting}

In 1976, the Liberation Tigers of Tamil Eelam (known as LTTE or Tamil Tigers), who perceived Sri Lankan Government policies and actions discriminatory against the Tamil population, started to claim an independent Tamil state in the north and east of Sri Lanka. Their demands culminated in a civil war that lasted from 1983 - 2002 and resulted in 70,000 victims on the island (Bilger, 2006). After a cease-fire period that lasted almost six years, the Sinhalese dominated Sri Lankan Government (GOSL) and the Tamil Tigers went back to civil war in January 2008. Since then, the GOSL has been able to celebrate important war victories and has managed to re-gain most of the territory from the LTTE in north-eastern Sri Lanka. After capturing their political capital Killinochchi, the Sri Lankan army 'liberated' the Tigers' military stronghold Mullaitivu, which had been in LTTE command for 13 years. This leaves the LTTE in control of only a 300 square kilometre area in the Mullaitivu jungles. In January 2009 the Sri Lankan Government believed that "the war is 95\% over" and that it can “completely destroy the LTTE in 2009” (Zeit Online, 26.01.2009). The civil war and continuous political struggle have severely hindered socio-economic development in the country, and intergroup relations among Sri Lankan people are deeply shattered. 
The headquarters of A.G.S.E.P. is located between the western Sri Lankan villages Marawila and Nattandiya, about 50 kilometres north of the capital Colombo. This rural region has not been affected strongly by the ongoing civil war and is considered a rather safe area in Sri Lanka. Most local families work in the fishing or garment industries that Marawila and Nattandiya are famous for. The infrastructure in both villages is very basic, and public sport or event facilities are not available. To provide the community with a sport and leisure facility, in 2006 A.G.S.E.P. together with the German based aid organisation Friedensdorf International constructed the Peace Village Sport Complex in Nattandiya. The multi-purpose sport complex includes a small-field soccer and cricket pitch, a 25 metre outdoor swimming pool, a sports hall for indoor sports and seminar sessions, plus three housing facilities and one eating room which can accommodate up to 80 people.

The Peace Village is today managed and sustained by the local Marawila and Nattandiya communities, who are supported with expertise from A.G.S.E.P. and in-kind donations (such as sport equipment) from Friedensdorf International. Since 2007 the local communities have been organising regular inter-community sport event weekends with different ethnic youth groups from all over Sri Lanka. This research focuses on the second ever Intercultural Sport Meeting (ISM) weekend held at the Peace Village from $19^{\text {th }}-21^{\text {st }}$ January 2007, which provided multi-sport activities for local Sinhalese participants from Marawila and Nattandiya, Sinhalese and Muslim participants from the north western town of Anamaduwa, and Tamil participants from the north eastern Nilaveli community.

\section{Data Collection}

This study is underpinned by an interpretivist mode of inquiry, which suggests that access to reality can be socially constructed through language, consciousness and shared meanings (Crotty, 1998; Glesne, 1999; Neuman, 2003). Interpretivist research acknowledges that data 
are analysed through a process of induction, which means that the researcher constructs and reconstructs meaning in relation to the research question based on the realities of participants (Denzin \& Lincoln, 2005). According to Myers (1997), interpretivist studies aim to understand the context of a phenomenon through the meanings that people assign to it.

Findings of this research were derived from the analysis of two ex ante focus group discussions and 35 semi-structured ex post interviews with Sinhalese, Tamil, Muslim and international event stakeholders. The two focus groups consisted of one international organiser group and one community group, which contained eight participants each. The organiser group included A.G.S.E.P. staff who provided an 'inside view' of A.G.S.E.P.'s roles as a change agent in Sri Lanka. The second group included community members from all three major ethnic groups in Sri Lanka: Sinhalese, Tamil and Muslim. The community group was expected to bring about the local people's voice, their beliefs and opinions about A.G.S.E.P.'s role within the inter-community sport event development projects. The discussion included inter alia questions on the expected social consequences of the ISM event; on how to sustain and leverage event benefits; and on the roles and responsibilities of NGOs and volunteers in facilitating community development projects.

After the ISM event, 35 in-depth interviews were conducted with various event stakeholders from Sinhalese, Tamil, Muslim and European background, including community members, event organisers, participants, spectators, sponsors, media and government representatives. The interviewees talked from an ex post perspective on the different roles and responsibilities of A.G.S.E.P. at inter-community sport events. In cooperation with the change agent and the ethnic groups, the researcher identified key individuals from the main event stakeholders and from the three participating communities Marawila/Nattandiya, Anamaduwa and Nilaveli for the initial round of interviews. Further interview participants were accessed through the use of 
snowballing. The combination of community representatives previously known by A.G.S.E.P. and this snowballing method resulted in the researcher getting access to a wide spectrum of interviewees, ranging from local fishermen to high profile Members of Parliament. In cases where the participants' English proficiency did not allow adequate responses, they were assisted by local Sinhala and Tamil speaking interpreter. The interviews were taped with a digital recorder and subsequently transcribed. To guarantee a confidential yet personal presentation of findings, research participants were given pseudonyms.

\section{Data Analysis}

The combination of qualitative methods employed for this research was chosen to find out in depth about the different roles of the change agent A.G.S.E.P. within the community development projects in Sri Lanka. The interpretivist paradigm underpinning this study highlights that empirical findings should inform the codes, themes and patterns which emerge from the research, which suggests that categories should not be entirely imposed prior to data collection (Glesne, 1999; Neuman, 2003). The qualitative data analysis process can thus be described as "working with data, organizing it, breaking it into manageable units, synthesizing it, searching for patterns, discovering what is important and what is to be learned, and deciding what you will tell others” (Bogdan \& Biklen, 1982: 145). The computer software used to support these steps of analysis was NVivo 7, which assisted the researcher in integrating, indexing and coding the large amount of qualitative data. Within NVivo, the coding processes are reflected in the creation of free and tree nodes. While free nodes can be described as containers for storing data that "do not assume relationships with other concepts" (Beazley \& Richards, 2000: 25), tree nodes are those which allow for hierarchical organisation into categories and sub-categories. During the data analysis process both free nodes and tree nodes were used. This resulted in a better understanding of relationships of the 
data and structures of emerging arguments, and allowed for the coding and reconceptualising of data into nine change agent roles and responsibilities.

\section{Findings}

The aim of this research was to gain a clearer understanding of the different roles and responsibilities of a change agent in facilitating community development through events. Table 1 below provides a snapshot of the foci that arose from the focus group discussions and individual interviews. The table highlights the commonalities and differences between the roles and responsibilities identified by the local communities and people working for the international change agent. The first column of the table shows the nine change agent roles and responsibilities identified by the respondents. The references made by the change agent in relation to the specific roles and responsibilities is presented in column two, while the third column shows which roles were commented on by the local communities' focus group and interviews.

Table 1: Change agent roles and responsibilities

\begin{tabular}{|l|c|c|}
\hline Roles and Responsibilities & $\begin{array}{c}\text { Identified by } \\
\text { Change Agent }\end{array}$ & $\begin{array}{c}\text { Identified by } \\
\text { Communities }\end{array}$ \\
\hline Agent for Community Participation & $\checkmark$ & $\checkmark$ \\
\hline Networker & $\checkmark$ & $\checkmark$ \\
\hline Trust Builder & $\checkmark$ & $\checkmark$ \\
\hline Leader & $\checkmark$ & $\checkmark$ \\
\hline Socially Responsible Advocate & $\checkmark$ & $\checkmark$ \\
\hline Resource Developer & $\checkmark$ & $\checkmark$ \\
\hline Innovator & - & $\checkmark$ \\
\hline Financial Supporter & $\checkmark$ & - \\
\hline Long-Term Planner & $\checkmark$ & $\checkmark$ \\
\hline
\end{tabular}


Before discussing the different roles in more detail, it should be noted that some of the roles include comments and topics which overlap or link with other roles. They should therefore not be seen in isolation but in combination with each other.

\section{Agent for Community Participation}

Respondents describe several key characteristics a change agent should possess in order to be a suitable and convincing agent for community participation. These include the responsibilities of being a background supporter, an inclusive co-operator, and showing commitment towards a transfer of responsibilities to community groups. The change agent is expected to help realise ideas which are designed in such a way that they instigate a process of change towards increased community participation. Representative of the organiser focus group’s view, European organiser Ranil (FGO: 234-237) states:

I would like to see A.G.S.E.P. in the background and instigate things, without dominating a certain direction and giving too much of an input. A.G.S.E.P. should not be the organiser from above, but from behind. Initiation of a movement is the key factor, just helping to start things, before the movement can carry on through community participation.

Ranil sees the event organiser not as a dominant force that implements or dictates a predefined program, but as an inclusive supporter who values, encourages, helps and empowers the locals. In this case empowerment refers to the process of transferring responsibility and authority to the communities. Tamil community member Raj describes the purpose of this process as follows:

The [locals'] ideas and views will be amalgamated into the whole project, then they feel that this is part of their personal project. You know, that in particular is very important, because note: This is MINE, MY SOMETHING, not A.G.S.E.P.'s, which would be bad. No, this is MINE! (TC1: 317-320) 
Raj goes on to say that by giving the locals a voice and transferring power to them, the change agent will increase feelings of achievement and commitment among communities, and contribute to sustainable project development.

\section{Networker}

As a networker the change agent needs to provide opportunities for continuous social contact, integration and networking. Respondents argue that contact should be fostered a) on an interpersonal level, b) among groups, and c) between groups and formal institutions of power. The organisers of the ISM state that they tried to place special emphasis on efforts to bridge differences between disparate groups and to link communities with national and international teams and institutions. Volunteer Katrin (V4: 222-227) for example suggests that A.G.S.E.P. played a significant role in "keeping relationships between groups. [They were] important to keep the contacts between the teachers and the participating schools at the event.” At the same time A.G.S.E.P. was able to link the communities to outer groups, organisations and associations. For instance, the organiser focus group expected positive outcomes when linking the events to Peace Village International, suitable Governmental departments and the media:

It is very important to have VIPs at the event, politicians and outstanding personalities, who are more the centre of attention and who are able to publicise the events, the programs, and their message to the wider community. (FGO: 201-204)

Respondents acknowledge benefits such as the generation of publicity and community support through a functioning network, and therefore encourage the cooperation with local authorities. Famous Sri Lankan sport stars as VIPs as well as political chief guests are recognised as suitable ways for creating publicity and leveraging the event to wider circles. 


\section{Trust Builder}

The change agent's role of facilitating the building of trust is a precondition for the success of inter-community sport events in Sri Lanka. Respondents argue that impartiality, institutional trust and reputation/symbolism are important elements for the creation of fruitful relationships among ethnic communities and between the organiser and communities. The impartiality factor helps to convince the communities to participate in the events, as the international change agent is considered a fair and just link between groups. Without any political or ethnic affiliation, the change agent presents a 'point of trust' for all communities, who is able to attract individuals and groups from all different backgrounds. Muslim community member Walter explains:

I think it is important that they are impartial organisation which is not from Sri Lanka. It is a big impact, because if this was done by Sri Lankans we would not have the power to persuade or convince people from all communities to participate. When my ethnic group explains our ideas, people of the other ethnic communities would probably become suspicious. (FGC: 260-264)

Walter's perspective is shared by the Tamil spectator Jaly (A1: 209-213), who predicts that his own community would not be able to stage an intergroup event alone, "because the other communities will think that we are not doing the right thing”. He goes on to say that in the back of their heads the locals "are thinking about the war, but [A.G.S.E.P.] are neutral people doing the real thing.” For organiser Ranil, one reason for the local acceptance of A.G.S.E.P. is their purposely chosen politically neutral logo. He explains:

Our logo says 'Connecting Sportspeople', which is a very neutral statement. It does not give any ideas or links towards any political affiliation or philosophical direction, we are just connecting sportspeople. There are a boy and a girl, another boy and a girl, and we try to put a ball in between them and try to make people interact through the medium of sport. And that's it. (FGO: 220-224) 
Ranil highlights that the logo avoids any links or connections to political parties and instead focuses solely on the sport factor in intergroup relations. As a result, there was no bias or prejudice against the change agent.

\section{Leader}

The respondents expect a change agent to employ personnel with solid event management skills and expertise, good supervision and leadership qualities, and a strong strategic management focus. The local communities enjoy the expert contribution of A.G.S.E.P. and they indeed favour a strong initial involvement of the international organiser in event projects. Participant Walter (FGC: 257-259) describes A.G.S.E.P. as "the head of things, the main body who needs to be firm.” He argues that “A.G.S.E.P. is enabling things that otherwise would not happen” and suggests that "others, like the participants and their communities, will be ok to join and help”, but not to lead. This argument proposes that the change agent's involvement in the community events provides locals with a sense of security and comfort. Volunteer Katrin points out that specific event know-how and the coordination of different strategic and operational management areas are necessary components for the staging of a sport event. She says:

When you are an event expert, you can organise everything much better than if you were just, you know, some amateur. You have to supervise many things: financial things, management and so on, and control everything, keep in contact with so many things. And when you're an expert it goes so much easier and faster. (V4: 266-270)

Katrin argues that the experts' experience and know-how will benefit the strategic and sustainable management of sport events, and she suggests that specific skills and knowledge can be passed on to local communities and support staff through workshops, presentations and practical learning sessions. 


\section{Socially Responsible Advocate}

Both the change agent and community respondents highlight the change agent's social responsibility and its role as an idealistic role model and advocate for peace and development ideals. The change agent is expected to demonstrate a high level of respect, commitment and dedication when working with a diverse group of people at intergroup development projects. The local communities argue that the organiser should employ socially skilled and responsible personnel that believe in idealism, altruism and social dedication, and who actively contribute to positive thinking and the stipulation of hope at the inter-community projects. For this, Dan recommends the inclusion of dedicated volunteers:

It is important to have some [sport event] experts, [but] I think it is more important to have one or two experts in social studies (...). The main thing is that they should definitely be idealistic and have the aim to help people, and to take part in an event that is good for other people and not for their own Curriculum Vitae. (V2: 236-240)

Katrin (V4: 256-259) agrees with Dan and highlights that volunteers "are much more concerned about what they do. If you get money for something, maybe you just do your work for money. But the volunteers they have a vision, they do it because they really want it.” It is her belief that volunteers possess the altruistic qualities required to make a difference in developing countries.

The locals further believe that to be a role model for the wider community, the change agent needs to embody the vision of peaceful togetherness among different groups. A.G.S.E.P. itself is expected by the locals to cooperate as an ethnically mixed work group, which encourages the inclusion of employees and volunteers from all ethnic communities and international groups. Walter states: 
[There was a] great mix of Sinhalese, Tamils, Muslims, Germans, Austrians, French and people from Cameroon. So A.G.S.E.P. "lives" this ethnic diversity themselves, which makes the organisation trustworthy of what they are saying and preaching. (...) It also shows to the communities that multi-culturalism and ethnic togetherness can be a success story. (FGC: 349-354)

By providing an intercultural management framework, the community is able to relate to the change agent, its staff and volunteers and may increase their trust in the organisation and the overall event concept.

\section{Resource Developer}

Respondents identify the change agent's role as being a developer of skill, talent and resources. Particularly the community members make a strong point that responsibilities such as providing access to sport and event facilities, developing culturally relevant skills, and contributing to sport development should be exercised by the change agent. A.G.S.E.P.'s cooperation with Peace Village International allows local communities to experience sport events in the less developed rural parts of Sri Lanka. Here, A.G.S.E.P. is providing and teaching event participants and contributors new resources, skills and talents through intercommunity activities. Kumi claims that many locals had access to a sport centre and a swimming pool for the first time in their lives:

When it comes to the rural areas, people have no way to know this table tennis. Some children wouldn't have even seen it. Or tennis... I mean, it's a kind of sport here which only rich people play. (...) I know that most of these students [have] never seen a swimming pool. You see, because in our rural areas we do not have such facilities. (SC2: 276-280)

A.G.S.E.P. places a strong focus on the combination of fun and educational activities during its events. Sugi, who lost several family members during the Tsunami disaster in December 2004, praises A.G.S.E.P. for their proactivity in developing specific skills: 
Language was one thing that the students learnt. And swimming was another one. And the sports were also very nice. I think, however, the swimming pool is the most important, because Sri Lanka is surrounded by the sea. So when the next Tsunami comes we would die if we didn't know how to swim. (TC2: 334-340)

The swimming lessons are valued by the local communities as both an entertaining sport and a lifesaving activity. In line with Sugi, the majority of people argues that the change agent's development focus should be on general sport and swimming skills combined with sociocultural activities (such as language classes, dancing and arts and craft). These skills people can use in their daily lives, unlike specific talent development for professional purposes.

\section{Innovator}

There is overall agreement that the change agent needs to develop new project ideas and creative concepts to make a real difference in the divided Sri Lankan society. A.G.S.E.P. has to differentiate its activities from other aid programs to attract interest and faith in their work, as too many NGOs in Sri Lanka have not performed to their expected standards. Ina (FGC: 233-236) explains that because of bad experiences "no one wants to hear about NGO projects anymore. The term NGO is becoming associated with something negative.” To positively differentiate itself, A.G.S.E.P. encourages innovation and allows for local participation and involvement in its development efforts. Karla recommends:

In comparison to many other programs, A.G.S.E.P. is focusing on participation and that is vital! The young generation does not want to have another discussion round or speeches from VIPs, even if that is all held in a nice room with air conditioning and stuff like that. They want to actively be involved, have fun and express their feelings like this. (FGC: 339-343)

A focus on participation in innovative inter-community concepts is mentioned by the local communities as the key element of positive distinction from other NGOs in Sri Lanka. 


\section{Financial Supporter}

The Sri Lankan interview respondents value the financial support received by the international change agent. Two key components are highlighted as elements of this role, first, monetary contributions to the communities, and second, the establishment of links towards sponsors and aid organisations. In a country where the physical infrastructure in regional areas is heavily underdeveloped, direct financial means such as funds and international aid contributions are valued by the communities as necessary support for the establishment of facilities (e.g. sport grounds, accommodation for sportspeople, and swimming pools). While A.G.S.E.P. provides sport equipment to event participants, its link with Peace Village International, helped to generate the funds for establishing the sport facilities. At the same time, A.G.S.E.P. supports the communities by providing free transportation to the event site, which according to Ina (FGC: 296-297) is crucial particularly for the "people from the east, for whom A.G.S.E.P. organises the long and scary transport to the west”.

\section{Long-Term Planner}

The role of the change agent as a long-term planner for sustainable community development is d'accord with a strong focus on a strategic bottom-up event management approach. The organisers highlight that simply providing activities during the event is not sufficient, but that leverage should be sought from the events to develop the positive socio-cultural impacts. Only when immediate impacts are turned into long-term outcomes and future activities of positive contact are provided, can benefits be sustained and promoted beyond event borders. Tom (O2: 229-232) describes A.G.S.E.P.'s strategic long-term focus as highly valuable for a continuous exchange of people from different ethnic groups. He argues that A.G.S.E.P.'s strategic direction of building “a Peace Village in Nilaveli and in Tangalle (southern Sri Lanka) and in Anamaduwa will allow for a real exchange of the different ethnic groups.” Tom and Marco propose that more sport centres, events, community initiatives and government 
support are needed in order to reach and activate more people, schools, sport associations and the media to spread the peace message all over the island. For this to eventuate, the recently signed Memorandum of Understanding between A.G.S.E.P. and the Ministry of Rehabilitation, Resettlement and Refugees (MRRR) is expected to be of strategic benefit.

\section{Discussion}

The findings show that within a social development context a change agent needs to fulfil at least nine roles before, during, and after the staging of inter-community sport event projects. Before the projects, the change agent has to encourage communities to participate in the event creation process by providing an innovative, creative and suitable platform for interaction and network building. During the project management, the change agent needs to facilitate and support communities as a background force, promoting social values and assisting in the development of skills and talents. After the projects, the change agent needs to transfer management responsibilities to the local groups, in an attempt to empower them for future projects and continuous development. Importantly, during all stages of this strategic management process, the change agent needs to be an impartial mediator and facilitator between communities.

This research found that the role of being an agent for community participation includes the responsibilities of being a background supporter, inclusive co-operator and advocate for local responsibility. Sanoff (2000) had outlined that the two overriding purposes of community participation for development are (1) to involve people in design and decision-making processes, and (2) to provide people with a voice and promote a sense of community by bringing people together who share common goals. In support of Sanoff's argument, this research demonstrates that a change agent cannot serve as a dictating force but should instead 
be a supportive facilitator of bottom-up community projects, who tries to encourage involvement, participation and cooperation between residents, management, and community organisations.

The presence of a change agent provides communities with comfort and confidence. It was demonstrated that the change agent needs to be strongly involved in the initial stages of intercommunity sport events, as without adequate professional support, communities would be overwhelmed and incapable of managing events. While previous sport related intergroup studies by Stidder and Haasner (2007), Burnett (2006), Sugden (2006) and Lawson (2005) had shown that change agents play a central role within the entire inter-community development process, this research argues for a gradual reduction of change agent input over time. Once communities have established reciprocal trust amongst each other and have learned project management skills, responsibilities of local contributors should increase progressively in a process towards local empowerment and ownership. The philosophical approach that underpins this gradual development process towards community empowerment is illustrated in Figure 2 below.

Program development over time

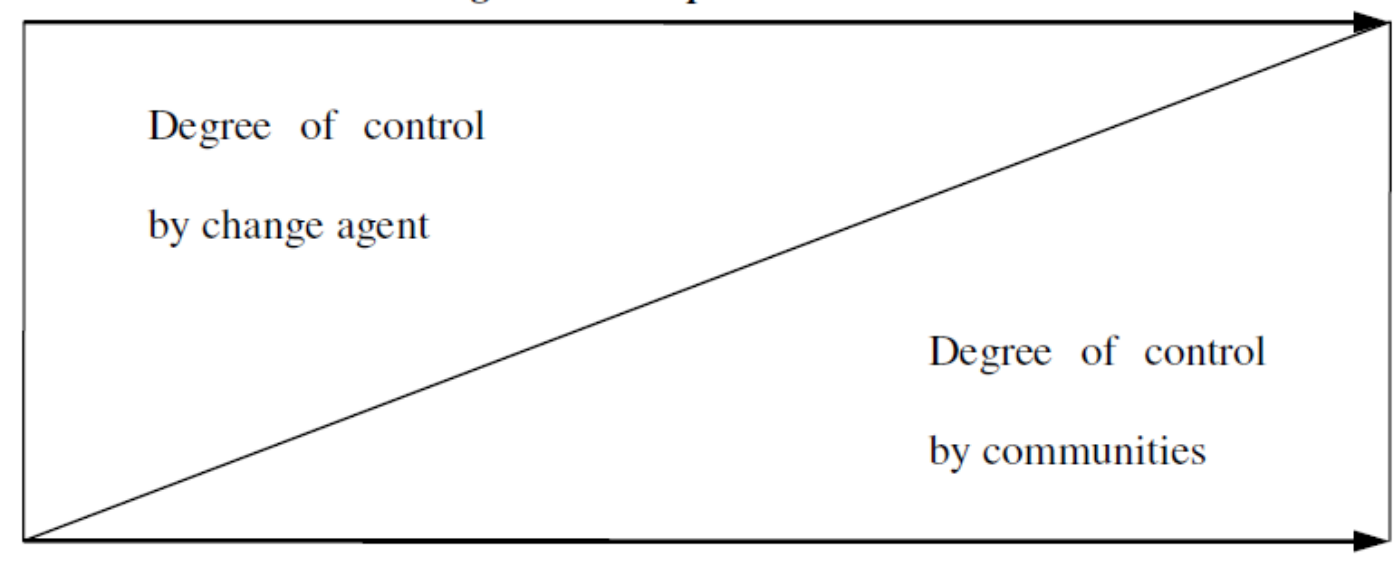

Continuum of individual projects 
The 'Model of Community Empowerment' illustrates that communities and change agents have a varying degree of control of the different individual projects that form part of an overall development program. Initially, change agents are largely in control of project planning and management processes, while the degree of community responsibility is low. Critically, it is the change agent's responsibility to understand at what time it is suitable to start the process of transferring knowledge, skills, responsibility and ultimately control to the communities. This research found that if it is done too early, the communities will revert to social exclusion and perhaps even violence; if it is done too late, the communities may lose interest in the projects, and/or may develop a colonial, paternalistic type of relationship with the change agent. While the way towards community empowerment and ownership of events may be a long and challenging one, people expect it to contribute to a culturally adequate setup before the events, higher participation and satisfaction at the events, and sustainable community empowerment in general.

During the entire event management process, the importance of a change agent's impartiality cannot be underestimated. Stidder and Haasner (2007), Sugden (2006) and Burnett (2006) highlighted that when dealing with sport projects in divided societies an external and impartial force can facilitate and advance social development processes through mediating and encouraging discussions. This research confirms that within politically delicate environments an external impartial change agent is considered an important 'bridge builder' between groups. A.G.S.E.P. was accepted by Sinhalese, Tamils and Muslims as an unbiased mediator among the communities, as the organisation did not hold any political or ethnic affiliation with any Sri Lankan group. As an impartial force, the change agent provided a point of trust for communities and through this increased the chances for continuous participation, commitment, confidence and achievement. 
In her research on peace-building within the Sri Lankan society, Orjuela (2003) pointed out that the social, economic and political crises in Sri Lanka have often hindered local empowerment. She argues that a full contribution and integration of all communities into development projects is a difficult task, particularly when trying to include the Tamil population from the LTTE controlled north-eastern areas of the country. This dilemma highlights the change agent's important role as a networker and social integrator in Sri Lanka. A.G.S.E.P. was required to have good networking and communication skills, which allowed for the bringing together of groups, the bridging of differences, and the establishing of links to disadvantaged communities and supporting stakeholders. This was exemplified through A.G.S.E.P.'s important link with the aid organisation Peace Village International, and their cooperation with and support from both the Sri Lankan Government and leading Tamil sport associations.

To grow the peace campaign and leverage event benefits to the wider community, cooperation with external stakeholders needs to be extended. Chalip (2006) argued that ancillary events can provide a great opportunity for participants, spectators and the host community to maximise event benefits. In support of his argument, this research found that event-related activities such as event management workshops, community festivals and after-event parties can be staged to maximise events' social utility. To realise these projects, local potential, ideas and resources should be encouraged by the change agent, so that communities are largely in control of linking the event with (culturally) relevant activities. Local responsibility should also increase in the financial management of follow-up projects. Interestingly, the communities identified the role of a financial supporter as a key element of the change agent's work, whereas the international respondents did not mention this responsibility at all. This suggests that the change agent needs to make clear that communities need to be selfsupportive through realising local resources, support and input in the long-run. 
One way of realising local potential is through linking the event to the governmental sector. While O’Brien (2007) illustrated community events' potential for business leverage, respondents in this study believed that political leverage can be gained from inter-community events. Once politicians are convinced about the social potential of inter-community sport events, they can promote, multiply and leverage the events' social purpose through their political network. Further, the government can contribute politically and financially to the establishment of additional sport event sites, which presents an important step towards sustainable socio-economic development.

At the ISM the communities' inexperience in event management prevented local groups from engaging in leveraging activities. The communities were predominantly focused on immediate impacts and had not realised the long-term potential of events. To activate this potential, it is the change agent's role to educate community members about strategic management practices. In an attempt to achieve local empowerment, Burnett (2006), Sugden (2006) and Stidder and Haasner (2007) highlighted that experienced sport experts can support local parties with community building knowledge and educational activities at events. Building on their recommendation, opportunities for education should be strategically designed around the event. A.G.S.E.P. could, for example, engage local coaches, teachers and community leaders in collaborative group work sessions on event creation, event planning, or event leveraging. External knowledge such as methods, skills and activities can thus be transferred under a 'train the trainers' approach, which can eventually benefit the community at large. 


\section{Conclusion}

In cooperation with local communities, change agents can create 'fresh spaces' for intergroup contact and celebration, where people from different backgrounds get the chance to work, learn, and celebrate with each other. Inter-community sport events have the potential to reduce social distance among groups, and result in local empowerment and sustainable development for participating communities. The big challenge for the change agent is to reconcile diversity among communities, help transfer event management knowledge, and assist in creating an exciting event atmosphere which meets the needs of all participating groups.

Within this strategic inter-community development process, the change agent holds nine important roles and responsibilities. These include being an agent for community participation; building trust; establishing networks; providing leadership; acting socially responsible; developing resources; being innovative; providing financial support; and planning strategically for the long-term sustainability of projects. The change agent needs to fulfil these roles to secure active community participation, to achieve positive socio-cultural event outcomes, and to provide a framework for sustainable inter-community development beyond event borders. These findings contribute to a greater understanding of the involvement of external change agents in conflict-resolution projects, and they highlight the potential for social and political event leverage. Only if change agents strategically define, develop and support projects as impartial partners, inter-community sport events can make a modest contribution to wider efforts to promote a peaceful togetherness and local empowerment in divided societies. 


\section{References}

A.G.S.E.P. Website. (2008). A.G.S.E.P. Profile. Retrieved 10.05 .2008 from http://www.agsep.com/page.php?id=157

Arai, S., \& Pedlar, A. (2003). Moving beyond individualism in leisure theory: A critical analysis of concepts of community and social engagement. Leisure Studies, 22, (July 2003), 185-202.

Avery, G. (2004). Understanding Leadership. London: Sage Publications.

Beazley, P., \& Richards, L. (2000). The NVivo qualitative project book. London: Sage Publications.

Bilger, A. (2006, 16. Juni 2006). Kriegsangst im Urlaubsparadies. Der Spiegel Online from http://www.spiegel.de/politik/ausland/0,1518,421813,00.html.

Bogdan, R. C., \& Biklen, S. K. (1982). Qualitative research for education: An introduction to theory and methods. Boston: Allyn and Bacon.

Botes, L., \& van Rensburg, D. (2000). Community participation in development: nine plagues and twelve commandments. Community Development Journal, 35 (1), 41-58.

Burnett, C. (2001). Social Impact Assessment and Sport Development: Social Spin-Offs of the Australia-South Africa Junior Sport Programme. International Journal for the Sociology of Sport, 36 (1), 41-57.

Burnett, C. (2006). Building Social Capital through an 'Active Community Club'. International Journal for the Sociology of Sport, 41 (3-4), 283-294.

Burnett, C., \& Uys, T. (2000). Sport Development Impact Assessment: Towards a Rationale and Tool. S.A. Journal for Research in Sport, Physical Education and Recreation, 22 (1), 27-40.

Chalip, L. (2004). Beyond impact: a general model for host community event leverage. In B. Ritchie \& D. Adair (Eds.), Sport tourism: Interrelationships, impacts and issues (pp. 226-252), Clevedon: Channel View

Chalip, L. (2006). Towards Social Leverage of Sport Events. Journal of Sport and Tourism, 11 (2), 109-127.

Chalip, L., \& Leyns, A. (2002). Local Business Leveraging of a Sport Event: Managing an Event for Economic Benefit. Journal of Sport Management, 16 (2), 132-158.

Chalip, L., \& McGuirty, J. (2004). Bundling sport events with the host destination. Journal of Sport Tourism, 9 (3), 267-282. 
Crotty, M. (1998). The Foundations of Social Research. St. Leonards, Sydney: Allen \& Unwin.

Denzin, N. K., \& Lincoln, Y. S. (2005). The SAGE handbook of qualitative research (3rd ed.). Thousand Oaks: Sage Publications.

Gasser, P. K., \& Levinsen, A. (2004). Breaking Post-War Ice: Open Fun Football Schools in Bosnia and Herzegovina. Sport in Society, 7 (3), 457-472.

Glesne, C. (1999). Meeting Qualitative Inquiry. In C. Glesne \& A. Peshkin (Eds.), Becoming Qualitative Researchers: An Introduction (2nd ed., pp. 1-17), New York: Longman

Gschwend, A., \& Selvaranju, U. (2007). Psycho-social sport programmes to overcome trauma in post-disaster interventions. Biel/Bienne: Swiss Academy for Development (SAD).

Hariharan, R. (2006). Intentions and Capabilities of Reluctant Partners. In B. Raman, N. Sathiya Moorthy \& K. Chittaranjan (Eds.), Sri Lanka: Peace Without Process (pp. 135-162), Colombo: Vijitha Yapa Publications

Henley, R. (2005). Helping Children Overcome Disaster Trauma Through Post-Emergency Psychological Sports Programs (Working Paper). Biel/Bienne: Swiss Academy for Development (SAD).

Hollnsteiner, M. R. (1979). Mobilizing the Rural Poor Through Community Organization. Philippine Studies, 27, 387-416.

Ife, J. W. (1995). Community development: creating community alternatives - vision, analysis and practice. Melbourne: Longman Australia.

Kellett, P., Hede, A.-M., \& Chalip, L. (2008). Social Policy for Sport Events: Leveraging (Relationships with) Teams from other Nations for Community Benefit. European Sport Management Quarterly, 8 (2), 101-122.

Kramer, R. M., \& Specht, H. (1975). Readings in community organization practice (2nd ed.). Englewood Cliffs, N.J.: Prentice-Hall.

Lawson, H. A. (2005). Empowering people, facilitating community development, and contributing to sustainable development: the social work of sport, exercise, and physical education programs. Sport, Education and Society, 10 (1), 135-160.

Michell, C. (1990). Mediation. In P. Smoker (Ed.), Reader in Peace Studies (pp. 26-32), Oxford: Pergamon Press

Midgley, J. (1986). Community Participation, Social Development and the State. New York: Methuen. 
Myers, M. D. (1997). Qualitative Research in Information Systems. MIS Quarterly, 21 (2), 241-242.

Naparstek, A. J., Dooley, D., \& Smith, R. (1997). Community Building in Public Housing. Washington, DC: U.S. Department of Housing and Urban Development.

Neuman, W. L. (2003). Social research methods: qualitative and quantitative approaches (5th ed.). Boston; London: Allyn and Bacon.

O'Brien, D. (2006). Event Business Leveraging: The Sydney 2000 Olympic Games. Annals of Tourism Research, 33 (1), 240-261.

O'Brien, D. (2007). Points of Leverage: Maximising Host Community Benefit from a Regional Surfing Festival. European Sport Management Quarterly, 7 (2), 141-165.

O'Brien, D., \& Chalip, L. (2007). Executive training exercise in sport event leverage. International Journal of Culture, Tourism and Hospitality Research, 1 (4), 296-304.

O'Brien, D., \& Chalip, L. (2007). Sport events and strategic leveraging: pushing towards the triple bottom line. In A. Woodside \& D. Martin (Eds.), Advancing tourism management (pp. 318-338), Cambridge, MA: CABI Publishing

O'Brien, D., \& Gardiner, S. (2006). Creating sustainable mega-event impacts: Networking and relationship development through pre-event training. Sport Management Review, $9(1), 25-48$.

Orjuela, C. (2003). Building Peace in Sri Lanka: A Role for Civil Society? Journal of Peace Research, 40 (2), 195-212.

Reid, S. (2003). Community Participation in Rural Events: The Potential to Develop and Utilise Social Capital. In K. Weber (Ed.), Advances in Convention, Exhibition and Event Research, pp. 42-51. Hong Kong: Hong Kong Polytechnic University.

Reid, S. (2006). The Social Consequences of Community Events in Rural Areas: A Stakeholder Perspective. Ph.D. Thesis, University of Queensland, Brisbane.

Sanoff, H. (2000). Community participation methods in design and planning. New York: John Wiley \& Sons.

Schulenkorf, N. (2008). A.G.S.E.P., Sri Lanka. In J. Carlsen, J. Liburd, D. Edwards \& P. Forde (Eds.), Innovation for Sustainable Tourism: International Case Studies (pp. 8593), Sydney: University of Technology, Sydney Available: http://www.besteducationnetwork.org/books/pdf/2007/Chapter\%209.pdf.

Schulenkorf, N. (2009). An ex ante framework for the strategic study of social utility of sport events. Tourism and Hospitality Research, 9 (2), 120-131. 
Skinner, J., Zakus, D., \& Cowell, J. (2008). Development through Sport: Building Social Capital in Disadvantaged Communities. Sport Management Review, 11 (3), 253-275.

Spergel, I. A. (1969). Community problem solving: the delinquency example. Chicago: University of Chicago Press.

Stark, S., \& Torrance, H. (2006). Case Study. In B. Somekh \& C. Lewin (Eds.), Research Methods in the Social Sciences, Thousand Oaks, Calif.: Sage Publications

Stidder, G., \& Haasner, A. (2007). Developing outdoor and adventurous activities for coexistence and reconciliation in Israel: an Anglo-German approach. Journal of Adventure Education and Outdoor Learning, 7 (2), 131-140.

Stiglitz, J. E. (2002). Participation and Development: Perspectives from the Comprehensive Development Paradigm. Review of Development Economics, 6 (2), 163-182.

Sugden, J. (2006). Teaching and Playing Sport for Conflict Resolution and Co-Existence in Israel. International Review for the Sociology of Sport, 41 (2), 221-240.

Uruena, N. (2004). Citizen participation as a means of controlling corruption at the local level in Colombia. M.Sc. Thesis, Oxford University, Oxford.

Vail, S. (2007). Community development and sports participation. Journal of Sport Management, 21 (4), 571-596.

Willmott, P. (1988). Community initiatives: patterns and prospects. London: Policy Studies Institute.

Wilson, P. A. (1997). Building Social Capital: A Learning Agenda for the Twenty-first Century. Urban Studies, 34 (5-6), 745-760.

Zeit Online. (26.01.2009, 26. Januray 2009). Rebellen flüchten in den Dschungel. Die Zeit from http://www.zeit.de/online/2009/05/srilanka-rebellen-niederlage. 